\title{
WŁADYSŁAW ANDRZEJ SERCZYK (23 VII 1935 - 5 I 2014)
}

Odszedł od nas w pełni sił twórczych, pokonany przez chorobę, wspaniały historyk - uczony, niezrównany przyjaciel młodszego pokolenia - Profesor Władysław Andrzej Serczyk.

Profesor Władysław Andrzej Serczyk urodził się w Krakowie 23 lipca 1935 r. Ojciec Wojciech Serczyk był inżynierem rolnictwa, matka Waleria, z domu Włosik, była zaś nauczycielką. W latach 1952-1956 studiował na Wydziale Filozoficzno-Historycznym Uniwersytetu Jagiellońskiego. Pod kierunkiem profesora Jana Dąbrowskiego przygotował pracę magisterską pt. Krakowskie rzemiosło artystyczne wieku Odrodzenia.

Przez krótki okres zaraz po ukończeniu studiów historycznych był zatrudniony w Akademii Górniczo-Hutniczej, a następnie uzyskał propozycję asystentury od Antoniego Podrazy w ówczesnej Katedrze Historii Narodów ZSRR (od 1970 r. - Katedra Historii Europy Wschodniej) Uniwersytetu Jagiellońskiego. Pracował tam w latach 1956-1964 jako asystent, potem jako starszy asystent. Zainteresowania naukowe Profesora wiązały się z dziejami gospodarczymi na Ukrainie w okresie nowożytnym, czego owocem była książka pt. Gospodarstwo magnackie w województwie podolskim w drugiej połowie XVIII wieku opublikowana w Wydawnictwie Polskiej Akademii Nauk (Oddział w Krakowie) w 1965 r. i stanowiąca rozprawę doktorską, obronioną dwa lata wcześniej. Przechodząc od zagadnień stricte gospodarczych Profesor skoncentrował swe badania na dziejach społecznych Ukrainy, co zaowocowało z kolei następną książką poświęconą tym razem koliszczyźnie (Koliszczyzna, Zeszyty Naukowe Uniwersytetu Jagiellońskiego 193, Prace Historyczne, Zeszyty 24, UJ, Kraków 1968). Na jej podstawie przyznano Profesorowi stopień doktora habilitowanego w zakresie historii nowożytnej Europy Wschodniej. Powołany został w 1968 r. na stanowisko docenta, a w 1970 r. został kierownikiem wspomnianej Katedry Historii Europy Wschodniej Uniwersytetu Jagiellońskiego. 
Profesor Władysław Andrzej Serczyk poszerzył swe pole badawcze o problematykę Kozaczyzny w szerokim aspekcie wzajemnych stosunków i relacji w I Rzeczypospolitej. Tej tematyce poświęcił książki, które weszły nie tylko do kanonu obowiązkowych lektur dla studentów historii i innych kierunków, ale także zyskały sobie uznanie szerszego kręgu czytelników. Chodzi przede wszystkim o następujące tytuły: Na dalekiej Ukrainie. Dzieje Kozaczyzny do 1648 r. (pierwsze wydanie: Wydawnictwo Literackie, Kraków 1984) oraz Na płonacej Ukrainie. Dzieje Kozaczyzny 1648-1651 (pierwsze wydanie: Wydawnictwo „Książka i Wiedza”, Warszawa 1998). Ostatnia pozycja ukazywała się po tej dacie jeszcze kilka razy $(1999,2007,2009)$.

Fascynacja Profesora dziejami Ukrainy widoczna jest niemalże na każdej stronie Jego książek. Problemy, które nurtowały Go, niezmiennie dotyczyły ważkich kwestii związanych z istnieniem i upadkiem I Rzeczypospolitej w końcu XVIII w. Rola Ukrainy i jej dążenia do stania się pełnoprawnym i pełnowartościowym członkiem Rzeczypospolitej zajmowały szczególnie dużo miejsca w twórczości Profesora Serczyka.

Talent literacki oraz wyrazisty warsztat historyka sprawił, że wędrówki po dawnej Ukrainie są lekturą mądrą i napisaną piękną polszczyzną.

We wstępie do pierwszego wydania Na płonącej Ukrainie napisał Autor te oto słowa: „Tę książkę pisałem bardzo długo. Od chwili, gdy zamarzyło mi się wejście w epokę Sienkiewiczowskiego Ogniem i mieczem i napisałem początkowe zdanie pierwszego rozdziału, do postawienia ostatniej kropki swoistej wiechy zamykającej tekst - minęło co najmniej kilkanaście lat. [...] Będąc więc w pewnym sensie człowiekiem tamtej epoki. Wiedziałem, ile jej główni bohaterowie popełnili błędów, ile wypowiedziano w gniewie słów niepotrzebnych, ile na darmo przelano braterskiej krwi i jak łatwo zrezygnowano z przyznania racji słabszemu. To, co jawiło się przez pewien czas jako rzeczywista szansa utworzenia Rzeczypospolitej Trojga Narodów, przeobraziło się w utopię, fantazję marzycieli, daleką od jakiejkolwiek możliwości urzeczywistnienia. [...] Zagubiła się Kozaczyzna wśród wątpliwych sojuszników, mających na uwadze tylko własne interesy; zagubiła się też polska szlachta, niezdolna do zrozumienia prostego przecież faktu, że historia nie stoi przecież w miejscu, że dojrzewają nie tylko ludzie ale też narody" (Na płonącej Ukrainie, s. 5-6).

W sposób szczególny mają swój wyraz te słowa Profesora w obliczu rozgrywających się obecnie, gdy piszę to wspomnienie $w$ końcu stycznia 2014 r., wydarzeń na Ukrainie.

Wymienić tu również wypadnie syntezę, książkę Historia Ukrainy, która zawiera dzieje Ukrainy od czasów najdawniejszych po okres nam współ- 
czesny. Wydanie drugie, poprawione i poszerzone, ukazało się w 1990 r., a następne w latach 2001 i 2009. W 1976 r. Władysław A. Serczyk został profesorem nadzwyczajnym, a w 1983 r. otrzymał tytuł profesora zwyczajnego.

Profesor interesował się też dziejami Rosji, spod Jego pióra wyszły znaczące biografie Katarzyny II, Piotra I, a także Kultura rosyjska w XVIII wieku. Jest Autorem 38 edycji książkowych, 130 artykułów i rozpraw naukowych, 32 głosów w dyskusjach (w publikacjach), 94 recenzji i prawie 2 tys. artykułów popularnonaukowych oraz publicystycznych.

Badania archiwalne i biblioteczne prowadził poza krajowymi: w Rosji, na Litwie, Ukrainie, w Austrii, na Słowacji, w Niemczech, Stanach Zjednoczonych i Kanadzie.

W latach 1963-1964 był Wiceprzewodniczącym Biura Prasowego 600-lecia Uniwersytetu Jagiellońskiego, od 1970 r., o czym wspomniano - kierownikiem Katedry Historii Europy Wschodniej, w latach 1974-1978 - dyrektorem Biblioteki Jagiellońskiej, a w latach 1978-1981 był prorektorem UJ do spraw nauki i współpracy z zagranicą.

Od 1986 r. Profesor Władysław A. Serczyk związał się z Filią Uniwersytetu Warszawskiego w Białymstoku. Od września 1993 r. pełnił funkcję prorektora UW do spraw Filii, w latach 1996-1998 był dziekanem Wydziału Humanistycznego Uniwersytetu w Białymstoku. Profesor prowadził wykłady i seminaria $z$ zakresu historii Rosji i Ukrainy. W jednym $z$ listów napisanych do mnie w styczniu 2002 r., nie będąc już w Białymstoku, wspominał naszą uczelnię bardzo ciepło.

"Czuję się mocno związany z Białymstokiem i tamtejszym środowiskiem naukowym. Cieszę się jego sukcesami, martwię - niepowodzeniami. Jestem trochę taki, jak Matka Rodzicielka, co nie oznacza, bym zmienił płeć (do sprawdzenia!), lecz jedynie informuję o moich uczuciach".

Pracę w Rzeszowie podjął Profesor najpierw w 1998 r. w Wyższej Szkole Pedagogicznej, a następnie w Uniwersytecie Rzeszowskim, kierując przez wiele lat Zakładem Historii i Kultury Europy Wschodniej.

Profesor brał udział w wielu międzynarodowych konferencjach i sympozjach naukowych w Detroit, Moskwie, Kijowie, Brnie, Berlinie, Bukareszcie, Halle i wielu innych. Wykładał jako profesor wizytujący na uniwersytetach w Kijowie, Berlinie, Nowym Jorku, Edmonton, Wiedniu, Grodnie, we Lwowie, w Petersburgu, Kolonii, Düsseldorfie, Heidelbergu, Moguncji i Halle. Wchodził w skład Międzynarodowej Komisji Studiów Słowiańskich i Komitetu Słowianoznawstwa PAN. Był członkiem wielu rad naukowych, Komitetu Nauk Historycznych. Należał do Polskiego Towarzystwa Historycznego, wchodził w skład Komitetu Redakcyjnego „Harvard Ukrainian Studies” i in- 
nych. Pracował w dwóch komisjach rządowych: Komisji do spraw Rewindykacji Dóbr Kulturalnych i Polsko-Ukraińskiej Komisji do spraw Podręczników Szkolnych Historii i Geografii, której był przewodniczącym. Od 1998 r. był przez trzy kadencje z wyboru członkiem Centralnej Komisji do spraw Stopni i Tytułów. W rozmowach ze mną nie ukrywał zdziwienia $z$ powodu wielu przypadków, o których mówił z żalem i zażenowaniem, gdy przychodziło mu obserwować nieuczciwe i niekoleżeńskie zachowania - np. wówczas, gdy własna rada naukowa blokowała kandydata do tytułu w sposób niegodny gremium uczonych.

Profesor wykształcił liczne grono magistrów i doktorów w Polsce. Za swoje osiągnięcia naukowe i dydaktyczne, odznaczony został m.in.: Krzyżem Oficerskim i Kawalerskim Polonia Restituta, Złotym Krzyżem Zasługi, Medalem Komisji Edukacji Narodowej, Medalem 30-lecia PRL, Złotą Odznaką dla Miasta Krakowa, Złotą Odznaką Zasłużonego dla Białostocczyzny, tytułami Zasłużonego dla Archiwistyki Polskiej, Zasłużonego Działacza Kultury, Odznaką 1000-lecia Państwa Polskiego. Był honorowym członkiem Polskiego Towarzystwa Historycznego i Międzynarodowej Słowiańskiej Akademii Nauk. W 2006 r. otrzymał Nagrodę Specjalną "Przeglądu Wschodniego" za całokształt twórczości.

Największą radością, czego nie ukrywał w rozmowach i listach do mnie, były dla Niego Księgi - pierwsza dedykowana Profesorowi w 60. rocznicę urodzin oraz druga z okazji 75-lecia i 50-lecia pracy naukowej. Pierwsza nosząca tytuł $Z$ dziejów Europy Środkowo-Wschodniej powstała z inicjatywy młodych wówczas uczniów Pana Profesora w Białymstoku, zawiera Wykaz publikacji, 34 artykuły oraz na Wstępie życiorys Jubilata. Wśród autorów są uczniowie, przyjaciele, koledzy: Jerzy Kłoczowski, Leszek Podhorodecki, pisząca te słowa, Ryszard Łużny, Stanisław Aleksandrowicz, Janusz Kaczmarczyk, Stefan Kozak, Ryszard Torzecki i inni.

Druga Księga zatytułowana Między Odra a Uralem wręczona została Profesorowi na Uniwersytecie w Rzeszowie w 2010 r. Składają się na nią poza Słowem o Jubilacie, Tablicy Gratulacyjnej, czterdzieści cztery artykuły. Jak to zwykle bywa przy okazji jubileuszy, w księgach znajdują się artykuły nawiązujące do badań i zainteresowań autora, któremu księga jest dedykowana ${ }^{1}$. W przypadku Księgi wręczonej Profesorowi Władysławowi

1 Z dziejów Europy Środkowo-Wschodniej. Ksiega pamiątkowa ofiarowana prof. dr. hab. Władysławowi A. Serczykowi w 60 rocznicę Jego urodzin, red. E. Dubas-Urwanowicz, A. Mironowicz, H. Parafianowicz, Dział Wydawnictw Filii Uniwersytetu Warszawskiego w Białymstoku, Białystok 1995; tamże, [Wstęp] Redaktorów, s. 5-7; Wykaz publikacji, s. 9-110; Między 
Serczykowi mamy do czynienia $\mathrm{w}$ wielu przypadkach $\mathrm{z}$ kontynuacją przez Jego uczniów badań tego Uczonego, także z Jego inspiracjami, dyskretnymi podpowiedziami i wreszcie $z$ dyskusjami $z$ wieloma wątkami, które przewijały się w książkach, artykułach, wystąpieniach konferencyjnych Jubilata.

Profesora szczególną sympatią darzyli młodsi badacze, ponieważ mimo nawet ostrej krytyki w wielu dyskusjach z Nim prowadzonych, zawsze czuło się Jego dyskretną przyjaźń. Miał przy tym niezwykłe poczucie humoru. Gdy w 2008 r. rozmawialiśmy na temat unii hadziackiej, zwrócił mi uwagę, że niektóre tematy chwilowo się Jego zdaniem wyczerpały, że możemy jedynie dodać jeszcze więcej szczegółów, ale nie zmienią one całości obrazu. Przy rozmaitych takich okazjach Profesor zastanawiał się nad współczesną rolą historyka. W jednym z listów z marca 2009 r. napisał do mnie te słowa:

„Trzeba się poważnie zastanowić nad współczesną rolą historyka-uczonego, bo idąc dalej w obecnie obranym kierunku zaczniemy gryźć własny ogon i będziemy dociekać, jak niewydarzeni entomolodzy, dlaczego niektóre muchy mają tylko pięć łapek, a nie sześć. Może straciły ją w ucieczce przed pająkiem? [...] Musimy sobie wreszcie zdać sprawę z tego, że dorabianie, nawet ładnych ozdóbek do istniejącego już łańcuszka, nie jest procesem twórczym. Lecz majsterkowaniem rzemieślnika, którego nie stać na w pełni samodzielne dzieło lub wykreowanie nowego kierunku w sztuce. [...] Potrzebne jest nam całkiem nowe spojrzenie na świat przeszłości i podjęcie kolejnych, prawdziwie wielkich problemów".

Z Profesorem spotykałam się m.in. w czasie międzynarodowych konferencji czy Komisji Historycznej Polsko-Ukraińskiej. Do dziś mam przed oczyma wspólne spotkania historyków polskich i ukraińskich z lat 90. ubiegłego już wieku w Kamieńcu Podolskim, Kijowie, Warszawie, Krakowie czy Przemyślu. Zawsze był słuchany niezwykle uważnie, Jego głos liczył się bardzo, choć mówił często o rzeczach trudnych i nie łatwo przychodziło przyznawać $\mathrm{Mu}$ rację. Czas już pokazał, że się w wielu ocenach historycznych nie mylił. Bardzo nam Go brakuje. Cześć Jego pamięci!

Teresa Chynczewska-Hennel (Warszawa-Białystok)

Odra a Uralem. Księga dedykowana Profesorowi Władysławowi Serczykowi, red. W. Wierzbieniec, Rzeszów 2010; tamże, Słowo o Jubilacie, autorstwa P. Uruskiego i W. Wierzbieńca, s. 9-12. Wiadomości dotyczące życiorysu naukowego Prof. Władysława Serczyka wykorzystane zostały z obu tekstów. 